\title{
ALK Gene Product
}

National Cancer Institute

\section{Source}

National Cancer Institute. ALK Gene Product. NCI Thesaurus. Code C150444.

A protein encoded by the ALK gene. 